\title{
UTILIZING RECORDED ENGLISH DIALOGUES IN TEACHING ENGLISH WORD STRESS TO ISLAMIC HIGHER EDUCATION STUDENTS IN INDONESIA
}

\author{
Abdul Gafur Marzuki \\ Institut Agama Islam Negeri (IAIN) Datokarama Palu \\ J1. Diponegoro No.23, Lere, Palu Barat., Kota Palu, Sulawesi Tengah, Indonesia \\ Email: gbudiperwira@gmail.com
}

Received: 03, 2019. Accepted: 07, 2019. Published: 07, 2019.

\begin{abstract}
The objective of this study is to know the effectiveness of recorded English dialogues in developing the students understanding of English word stress for Islamic Education students. The study employed the classroom action research design. The subject of this study was undergraduate EFL students at the Islamic Education Department in 2018/2019 academic year. The data were collected through four research instruments: observation checklist, questionnaire, field notes, and test. The result of study shows that teaching English word stress through the utilizing recorded English dialogue performed by the researcher is effective to develop students understanding of English word stress. The primary criteria to judge that the students have development are that from the score they gained from two phases of test. In the first test, the students' development reached 56.25\%. Meanwhile, in the second test, students' development attained $81.25 \%$. Since learning achievement is calculated based on the number of students who get the target score, so it can be stated that the learning achievement has been attained.
\end{abstract}

Keywords: Islamic University, Listening Dialogues, Word Stress in English, Islamic Education Students

\section{ABSTRAK}

Tujuan dari penelitian ini adalah untuk mengetahui efektivitas rekaman dialog bahasa Inggris dalam mengembangkan pemahaman mahasiswa tentang stres kata bahasa Inggris pada mahasiswa Pendidikan Agama Islam IAIN Palu. Penelitian ini menggunakan desain penelitian tindakan kelas. Subjek penelitian ini adalab mahasiswa EFL dijurusan Pendidikan Agama Islam FTIK IAIN Palu tahun akademik 2018/2019. Data dikumpulkan melalui empat instrumen penelitian: observasi, kuesioner, catatan lapangan, dan tes. Hasil penelitian menunjukkan bahwa pengajaran stres kata Inggris melalui pemanfaatan rekaman dialog bahasa Inggris yang dilakukan oleh peneliti efektif untuk mengembangkan pemahaman mahasiswa tentang stres kata bahasa Inggris. Kriteria utama untuk menilai bahwa mahasiswa memiliki perkembangan adalah dari skor yang mereka peroleh dalam dua fase tes. Pada tes pertama, perkembangan mahasiswa mencapai 56,25\%. Sementara itu, pada tes kedua, perkembangan mahasiswa mencapai 81,25\%. Karena prestasi belajar dibitung berdasarkan jumlab mahasiswa yang mendapatkan skor target, sehingga dapat dinyatakan bahwa prestasi belajar telah tercapai.

Kata Kunci: Pendidikan Tinggi Islam, Mendengarkan Dialog, Penekanan Kata pada Bahasa Inggris, Mahasiswa PAI

\section{INTRODUCTION}

English has long been the prominent foreign language studied by the students in Islamic higher education level in Indonesia. Teaching English, English word stress in particular, as one of the features of pronunciation, provides a great challenge for lecturer of English, especially when it is taught for Islamic education students. Students who learn English sometimes have different motivation, need, education, ability, goal, facilities, and economic sides (Marzuki, 2016). The English they learn differs from their native language. That is why in learning English as a foreign language, many Indonesian students find some difficulties (Bin Tahir, 2017). Here, the role of a teacher is definitely important. The teacher must do his/her duty to motivate, to facilitate, and 
to guide the students to learn and to master English for communicative purpose and pronounce it correctly with appropriate stress (Fudge, 2015; Marzuki, 2017).

In Indonesia, English as a foreign language has been taught from elementary schools to university level (Marzuki, 2016; Marzuki, Alim, \& Wekke, 2018). (Depdiknas, 2004) states “one of the purposes of teaching English is to enable students to communicate in English." However, there were still many students having difficulties in learning and applying it in their daily life. The researcher was interested in solving problems of pronunciation, especially word stress in English because pronunciation as one of the language components plays an important role in communication. Pronunciation is the production of significant sounds in terms of a given language code to distinguish sounds among languages and of achievement meaning in contexts of use (Rofiqoh, 2000) and word stress is the relative emphasis of the various syllables within a word, and it forms a very important part of the phonological shape of that word (Buck, 2001).

If someone mispronounces words, his/her interlocutor may misunderstand what he or she means. It might cause the conversation not running well. For instance, when someone says "beard", whereas he/she should have said "bird", the inaccurate sound could lead to misunderstanding to the listeners. Similarly, when someone says "ímportant or importánt" instead of "impórtant", the misplaced stress could change the meaning of the word and finally his/her interlocutor would have misperception.

The students might recognize words in writing but did not know their appropriate pronunciation particularly word stress in a speech (Gilakjani, 2012). On the contrary, they might know the words in spoken form but did not recognize them in writing because they were spelled quite differently from the pronunciation. They even did not know the words both in writing and in spoken form. There are some techniques of teaching pronunciation especially word stress in English (Gilakjani, 2012). One of them is through recorded English dialogues. They could see or read texts of the dialogues (because they had transcripts) and heard the language used directly from native speaker or non-native speaker (who has competence in speaking English). They might imitate their pronunciation, word stress in English, and acquired their sounds and patterns.

Based on the observation, problems faced by students in process of teaching and learning pronunciation especially words stress in English was as follows: firstly, students tend to follow Indonesian stress pattern in pronouncing English words. Secondly, an English word might have more than one meaning, different pronunciation, and different places of stress. As a result, it was still difficult for them to memorize and pronounce the English words appropriately and to determine position of the words' stress because misplaced of stress could change category/class of the words and their meanings.

(Gilakjani, 2012) reported the study of factors affecting EFL learners' English pronunciation learning. In addition, the research investigated the strategies for teaching pronunciation especially words stress unit. This topic can be one of the most challenging material for EFL learners to conquer and to possess good command. On the part of EFL teachers this word stress topic may be the least favorite topics for them to deliver for their EFL learners in their classroom. All students can perform better in learning the pronunciation (word stress) for English as a foreign language if their instructors invite them and ask them to take a part in the total learning process. Their learning success can be achieved if they have set their learning objectives. Pronunciation must be taken into account as a learning process that requires more than correct production of phonemes. In other words, it must be seen in the same light as grammar, syntax, and discourse that serves as a paramount part of communication. Studies have shown that intelligible pronunciation is seen as an important element of communicative competence for foreign language learners especially English in this context. With this in mind, EFL teachers must then design an achievable objectives that are applicable and suitable for their 
language learners' communication need. In the same vein, EFL learner must also show and engage their enthusiasm in their language learning process and actively glued in their own learning.

Based on this background, the researcher conducted his research about teaching English word stress through recorded English dialogues. He focused the research on English word stress and how to pronounce the English words. Therefore, the researcher was interested to solve the pronunciation especially word stress in English problem. To be more specific, the research question that is necessary answered was how effective is recorded English dialogues in developing the students understanding of English word stress?

\section{METHOD}

Action research is intended to overcome problems that have a direct application in setting where research was conducted. Sources of the problems faced by the students were typically identified by the teacher who thought that it was needed an immediate solution.

The researcher employed collaborative research approach. (McNiff, 2013) argues that collaborative action research involves at least two persons as the main actors of the study action and this research team works together to solve the problem in a single classroom research. The researcher and the collaborator would collaboratively design lesson plan, prepared instructional material and media, and implemented the action plan. The focus of collaborative action research is on both the processes and the outcomes of a change strategy, such as a staff development program. Teachers gain knowledge and skills, are more aware of options for change, and become more critical and reflective about their own practice (Fraenkel, Wallen, \& Hyun, 2011; Kemmis, McTaggart, \& Nixon, 2013; Stringer, 2008).

Classroom Action Research is carried out to have actual data. Therefore, McKernan, J. (2013) proposes the following steps: (1) identify an issue, interest or problem; (2) seek knowledge; (3) plan an action; (4) implement the action; (5) observe the action; (6) reflect on your observations; and (7) revise the plan. This study was took place at department of Islamic Education in one of state Islamic higher education in Palu.

In an attempt to achieve accurate and reliable data, the study deployed a field research by using some instruments, i.e. observation checklist, field notes, questionnaire, and test. To ensure that the study investigate students' understanding of the use of English word stress and to determine continuation of cycle, there is a need to establish criteria to classify success. This study therefore determined the criteria of success. Given the objectives of this study, teaching English word stress through recorded English dialogues, the criteria of success in this study adopted and modified the work of (Marzuki, 2016) as follows:

a. The students' participation in learning process should meet "high" category for at least $60 \%$ from the students' number (this was taken from observation checklist).

b. The students were able to know what syllable was stressed in a word from recorded dialogues (this was taken from questionnaire).

c. There were at least $65 \%$ learners achieved individual achievement at least 65 or greater than it (this was taken from achievement test).

\section{RESULTS AND DISCUSSION Research Preparation}

To prepare those instruments is important to do in order to make the research wellprepared. Corresponding to the above task, the researcher and the collaborator worked together preparing researcher instrument, instructional materials and media as well. The researcher provided some instructional materials and media which were necessary for teaching. Meanwhile, the collaborator multiplied observation checklist he used to observe the teacher's performance 
and students' response during the teaching process; and other instrument such as evaluation sheet and field notes. There were five main preparations the researcher and his collaborator before they did the action. The preparations corresponded to research instruments, in which they comprise observation checklist, questionnaire, field notes, criteria of success and test. Moreover, to conduct a smooth teaching learning process, the researcher also prepared teaching materials and teaching aids he employed in the teaching learning process.

1. Research Instruments

Research instruments were valuable to gain reliable data that was important for the researcher to analyze them. There are two advantages of preparing research instrument before the researcher conducted the researcher; the accomplishment of reliability and validity of the instruments themselves; and the reliability and the validity of the data (Marzuki, 2017).

Well-prepared research instruments lead the researcher to construct validity and reliability of them. It is considered important for the need of the researcher. Meanwhile, suitable instruments will highly determine the reliability and validity of the data. In references to the preparation on research instruments, the researcher considered that he has the established appropriate researcher instrument on the basis on research need. Moreover, the research instrument he utilized to collect data in accordance to the characteristic of the data. It means that the researcher has prepared appropriate researcher instruments before he and the collaborator were in action doing the research. He provided research instruments with kinds of the data he need to gain.

2. Instructional Material and Media

The preparation on instructional material and media was important to be done before the research was conducted. Preparation was closely related to teaching planning. Based on the findings, there were five items the researcher prepared or planned in relation to instructional materials and media. They consisted of lesson plan, teaching materials, teaching media, evaluation sheet, and scoring sheet. Toward these preparations, (Burden \& Byrd, 1999) state that there are thirteen advantages of planning. In teaching circumstances, the merits of planning may contribute to assist language teachers to:

a. Provide them a sense of direction, and through this, teacher boost their confidence and security. Planning can manage their position to stay on course and reduce teacher's anxiety when they come to language instruction.

b. Organize, sequence, and getting accustomed to language learning material.

c. Seek and prepare related-teaching materials and plan to apply various types of teaching media. This planning play a significant role when language teachers order their instructional supplies.

d. Deploy a variety of teaching strategies and activities over time.

e. Prepare to socialize with their language learners. This may include preparing a list of essential questions or guidelines for cooperative group learning activities.

f. Arrange for appropriate requirement and evaluation of students performance.

\section{Planning for the First Cycle}

The initial task for the researcher to do when he was about to begin the teaching learning process of the first cycle was to prepare lesson plan. Lesson plan contained time allocation, standard competence and basic competence, indicator for students' achievement in speaking class, teaching objectives, teaching materials, teaching method, teaching procedures used by the researcher, teaching resources, and evaluation. To do the prepare lesson plan for teaching is a must for a teacher before he or she conducts teaching learning process.

With respect to argument above, (Richard \& Renandya, 2002) stated that lesson plan is especially important for service teacher because they may feel more of a need to be in control 
before the lesson begins. They further state that lesson plan can benefit English teachers in the following ways:

a. A plan can help the teacher thinks about content, materials, sequencing, timing, and activities

b. A plan provides security (in form of a map) in the sometimes unpredictable atmosphere of a classroom.

c. A plan is a log of what has been taught.

d. A plan can help a substitute to smoothly take over a class when teacher cannot teach.

It is understandable that well-prepared lesson plan will contribute a sense of confidence for the teacher to teach (Marzuki, 2017). The teacher will feel secured from losing direction in the middle of the lesson if he previously organized lesson plan well. So, in response to the findings, the researcher developed a model of lesson plan that can provide him with guaranty for satisfactory teaching and for attaining instructional objectives.

Other components of lesson plan that the researcher should also consider to prepare were indicator and instructional objectives. Instructional objectives were necessary to be constructed by the researcher since they have sense of direction to lead the researcher and the students to achieve expected teaching learning objectives. One or more goals for each lesson will be set. Goal or objective in learning refers to the statement for condition which is wanted after student learn particular knowledge. Objectives commonly tell what the earner will be able to perform after they experience learning something (Burden \& Byrd, 1999; Perin, 2011). In line with the statement, the researcher constructed instruction objectives in respect to the language skill in which the students have to reach at the end of the lesson. Since the research emphasized on improving students speaking skill; so he specified instructional objectives on the area of the intended skill. Specifying instructional objectives means constructing a framework of instruction and focusing it to specific target of learning.

Instructional objectives should be explicitly stated in lesson plan to enable the teacher to control his teaching learning process to be in right path (Marzuki, 2017). What the researcher has done in his lesson plan was he explicitly stated instructional objectives and limited them on the basis of language skill that he needed to improve. Moreover, instructional objectives should be in line with the topic that the students are going to study. In the first cycle, the researcher served the students with the topic about "Stress pattern in English". In this matter, the researcher needed to include one of instructional objectives dealing with topic. So it is reasonable that instructional objectives should also be related to the topic.

In order to provide an accurate judgment about the successfulness of the teaching learning process, the researcher needed to construct indicators of achievement. Indicators must be with respect to instructional objectives, and must be in a harmony with basic competence and standard competence (Marzuki, 2017). The indicators of teaching learning achievement are useful to observe whether or not the instructional has been achieved. From the findings, it was found that the researcher arranged indicators of achievement by limiting them only in the area of development of speaking skill. Similar to instructional objectives, indicators of achievement was also arranged in accordance with the topic of the lesson. The expected teaching objectives that the researcher constructed in the lesson plan in the first meeting were as follows:

By the end of the lecture, the students are able to:

a. put the correct stress in verbs and unsuffixed adjectives and pronounce them appropriately.

b. practice a dialogue in pairs with good pronunciation and correct stress in verbs and unsuffixed adjectives placement.

\section{Researcher's Performance}

The researcher's performance was one of the necessary aspects of teaching learning process that the researcher needed to take into account (Akbari, 2015). It is because in Classroom Action 
Research, the teaching process that covers teacher's performance and students' response are considered the main facts that the researcher needs to expose. Both researcher's performance and students response or students' classroom participation are parts of important components to judge the successfulness of the teaching learning process.

To begin the class at pre-activity, the researcher offered students some questions after he responded to students' greeting and asked students' condition. The two activities above is a must for the researcher to do in response to provide students with sense of respect and care. If the researcher or the teacher promptly responds to students' greeting, they will feel that the researcher or teacher respect to them. Conversely, if the researcher or teacher as if ignored the greetings, it is possible to emerge students' discourage of teacher's or researcher's presence.

Furthermore, if the teacher begins the class by firstly asking students' condition, it will provide them with sense of care. The students will bear in mind that the teacher always cares about them whenever he enters into the classroom. On the contrary, the students will feel that the teacher doesn't care about their presence and they will think that the teacher fails constructing harmony relationship with the students whenever he comes to the classroom. It is a simple thing to do, so that the teacher should not think that asking students' conditions is only one of classroom routines that needs to be fulfilled.

To give clear explanation about teacher's or researcher's performance, the following are the steps that the researcher activities when in pre-activity, while activity, and post activity.

1. Pre-Activity

There were two primary activities the researcher did in pre-activity phase; they are a. instructing students about the objective of learning or classroom activities they are going to do. It implies sense that by giving clear instruction to students about the activities they are going to do, the teacher puts them into right direction. It was important thing done by a teacher before offering the task to students to complete. It always happened in the teaching learning process in which the teacher distributed task to the students in advance, it was then followed by instruction. Such procedure was considered less effective since the students have long been immersed understanding what the task wants them to do., then instructions was given. As a result, when the teacher instructed them how to complete the task, some of them had focused on reading task without paying attention to the teacher's instruction. b. Asking several questions to students directed him to the content of lesson and to explore students' prior knowledge the topic that the class will discuss. Preliminary questions are regarded as one of the main points in beginning the class. It is offers teacher valuable recognition of students' prior knowledge about the topic. Besides, it is it important for directing students to certain topic they will study.

2. While-Activity

While-Activity was usually called as the core teaching activity. This teaching phase was where the teacher and students are involved in rapid interaction. In rapid interaction, the teacher was in charge controls and guides students on task and the students are on action doing classroom task. The researcher found that there were two primary actions the teacher did in while teaching activity; a. giving brief explanation about the topic to students; b. distributing photocopy material containing a number of words that have been divided into groups; c. asking students to pronounce the words together; $d$. asking students to compare and analyze a number of words that have been divided into groups; e. explaining the students about the rules of word stress; f. providing students with chance to clarify the teacher's explanation; g. dividing students in groups or pairs; h. distributing dialogue text to each students; i. asking students to practice dialogue in pairs; $j$. playing recorded English dialogue then ask them to compare with their previous pronunciation and stress placement; $k$. writing down words that the students still mispronounce or misplace of stress and guide them how to pronounce the correct ones; 1. asking 
them to repeat and practice the words to improve their mispronunciation or misplace of stress; $\mathrm{m}$. controlling the students activities.

3. Post-Activity

Post-classroom activity was the place where the teacher and the students were nearly to end the class. The finding exposed that there were three activities $s$ that the researcher did in postactivity; they were a. providing reinforcement; b. flashing back to the previous classroom activity; c. administering homework.

a. Reinforcement was given in the form of comment about appreciation toward students' previous performance, such "well done, good job, nice work, excellent performance, and many other." b. to make sure that the students really recognized and understood the task given to them to complete, in post-activity, the researcher brought them into flashing back to the previous classroom activities. They were asking to practice the dialogue text, controlling and guiding the students' activities, and asking several questions related to the topic and sub topic; c. administering homework to students was the way the teacher to enrich students with learning experience. Furthermore, homework was valuable to judge students' attention in completing homework. It was also the way the teacher to activate students to study independently without being under supervision.

\section{Student's Participation in Teaching Learning Process}

Assessment should be thoroughly implemented during teaching and learning enterprises to allow teacher to come into the sound decision about their teaching and learning process. Holistic assessment should take into consideration students' participation in their effort to learn and master particular knowledge. Students' participation should be a concern for their teacher since they want to be acknowledged in their learning process. In line with this holistic assessment applied in students process and interaction during learning, (Burden \& Byrd, 1999) state that students' participation in the classroom during writing and reading can be measured by using provided charts. It is clear that to assess or to evaluate students' participation have resulted in a condition which minimizes their anxiety to lesson or any burden in dealing with several tasks in their classroom. There was a slight difference between Burden's and Byrd's way in observing students participation and the way this study applies the term of this educational matter. To measure students' classroom participation, this study applied observation checklist that contains three categories: low, mid, and high.

The researcher found that there were at least nineteen items concerning to students participation that the researcher covered in his findings. Those components are divided into three phases of teaching; pre-activity, while-activity and post- activity.

1. Pre-Activity

Students' participation in pre-activity was assessed based on their' involvement to classroom activity when the class was about to begin. It consisted of a. instructing students about the objective of learning or classroom activities they are going to do. It implies sense that by giving clear instruction to students about the activities they are going to do, the teacher puts them into right direction. It was important thing done by a teacher before offering the task to students to complete. It always happened in the teaching learning process in which the teacher distributed task to the students in advance, it was then followed by instruction. Such procedure was considered less effective since the students have long been immersed understanding what the task wants them to do., then instructions was given. As a result, when the teacher instructed them how to complete the task, some of them had focused on reading task without paying attention to the teacher's instruction. b. Asking several questions to students directed him to the content of lesson and to explore students' prior knowledge the topic that the class will discuss. Preliminary questions are regarded as one of the main points in beginning the class. It 
is offers teacher valuable recognition of students' prior knowledge about the topic. Besides, it is it important for directing students to certain topic they will study.

2. While-Activity

The components concerned with students' classroom participation in the middle of lesson covers five items. Those items were separately discussed in the following session. a. giving brief explanation about the topic to students; b. distributing photocopy material containing a number of words that have been divided into groups; c. asking students to pronounce the words together; d. asking students to compare and analyze a number of words that have been divided into groups; e. explaining the students about the rules of word stress; f. providing students with chance to clarify the teacher's explanation; g. dividing students in groups or pairs; h. distributing dialogue text to each students; i. asking students to practice dialogue in pairs; j. playing recorded English dialogue then ask them to compare with their previous pronunciation and stress placement; $\mathrm{k}$. writing down words that the students still mispronounce or misplace of stress and guide them how to pronounce the correct ones; 1. asking them to repeat and practice the words to improve their mispronunciation or misplace of stress; $\mathrm{m}$. controlling the students activities.

3. Post-Activity

The last phase in teaching learning process was post-activity. To assess students' classroom participation in this session, the teacher included three main components. a. reinforcement was given in the form of comment about appreciation toward students' previous performance, such "well done, good job, nice work, excellent performance, and many other." b. to make sure that the students really recognized and understood the task given to them to complete, in post-activity, the researcher brought them into flashing back to the previous classroom activities. They were asking to practice the dialogue text, controlling and guiding the students' activities, and asking several questions related to the topic and sub topic; c. administering homework to students was the way the teacher to enrich students with learning experience. Furthermore, homework was valuable to judge students' attention in completing homework. It was also the way the teacher to activate students to study independently without being under supervision.

\section{Student's Performance in Teaching and Learning Process}

Students' performance in the teaching and learning process can be observed from five elements in which the students were evaluated. This was done in this study to spot the difference in students' performance from session to session. It goes without saying that to assess or to evaluate students' performance have several benefits for students and they contribute to lessening their fear in learning lesson or dealing with complicated classroom task.

The components that the researcher used them as indicators to assess students' performance in the teaching learning process are student's enthusiasm, motivation, interest, response, and students' progress. The five components were carefully observed to make sure that the students have progress in classroom performance from one meeting to other meeting.

The result of the analysis toward students' classroom performance is going to be explained as follows: (1) Students' enthusiasm toward the teaching learning process in (a) most of the student in meeting 1 and 2 cycle I were in middle category; (b) most of the student in meeting 3 and 4 cycle I were in high category, (c) meeting 1 and 2 cycle II were in high category; and (d) meeting 3 and 4 cycle II were also in high category. From the data presentation, it can be concluded that the students have an improvement in terms of their enthusiasm when they were in the second meeting; and they could stand on the improvement up to meeting 4. (2) The analysis on students' motivation shows that (a) meeting 1, 2, 3, and 4 cycle I were in middle category; (b) meeting 1 and 3 cycle II were in middle category; (c) meeting 2 and 4 cycle II were in high category. From the description, it can be interpreted that the students were motivated to join the class. They competed to get teacher's attention in order to be provided with task to complete. (3) The finding concerns with student's interest explains that meeting (a) 1, 2, and 3 
cycle I were in middle category; (b) meeting 4 cycle I were in middle category; (c) meeting 1, 2, 3 , and 4 cycle II were in high category. The findings related to students' interest throughout classroom meetings expose a difference. If the students were in the middle category regarding to their interest in the first cycle; it is different from the second cycle. Since the researcher found that there was any significant progress in interest when they were in the second cycle. (4) Students' response toward the teaching learning process was one of the components that the researcher observed during teaching learning process. The result of observation shows that (a) meeting 1 cycle I is in low category; (b) meeting 2, 3, and 4 cycle I were in middle category; (c) meeting 1 and 2 cycle II were in middle category; and (d) meeting 3 and 4 cycle II were in high category. It seemed that the students did not have any spontaneous response toward teacher's instruction, given lesson until they were in the second meeting of cycle I. They achieved high category concerning to response when they were at meeting 3 cycle II. The researcher views that this kind of progress is categorized indolent. (5) It was found that student's progress changed from meeting to meeting; meeting 1 cycle I is in low category; (b) meeting 2 and 3 cycle I were in middle category; (c) meeting 1 and 2 cycle II were in middle category; and (d) meeting 3 and 4 cycle II were in high category. From the description above, the result of analysis can be concluded that the students attained the pick of progress when they were in the second meeting of cycle I.

This study is aimed at investigating students experience in learning word stress as a part of material they learn in pronunciation. The results of the study have confirmed the result of previous study conducted by (Gilakjani, 2012). The previous study conducted a research to explore factors influencing EFL learners' English pronunciation learning and the strategies for instruction. The study found that pronunciation especially words stress can be one of the most challenging topic to deal with on the part of EFL learners. On the other hand, the word stress topic has been one of the least favorite topics for instructor to deliver in the EFL classroom. All student can perform well in learning the pronunciation (word stress) of a foreign language if the instructor and the learners stick together to achieve their goals in the total learning process. There are a number of activities instructor can deliver to teach word stress correctly. Listening to recorded English dialogue can be a possible option to use in teaching and learning and lead student process to deal with perception exercises on duration of stress, loudness of stress, and pitch. These exercises will help students to learn the difference between stressed and unstressed syllables. For example, learners can trained to recognize where stress falls in words with two or more syllables by learning the rules of parts of speech and word stress (e.g., the primary stress is on the first syllable in compound nouns such as airplane, lapscape). Students can also use a pronunciation computer program, such as American Speechsounds, to study the duration and loudness of stress. This includes exercises on recognizing and producing weak, unstressed syllables. For example, one exercise facilitates students to identify computer voice recognition mistakes that have occurred because of mispronunciation of weak vowel forms (e.g., -Alaska if she wants to come with usll instead of -I'll ask if she wants to come with us).

Furthermore, (Pitt, 2009) found that students had to express the exposure to conversations so they will be able to hear variation in pronunciation. By using audiotapes and videotapes, teachers can give learners meaningful exposure to variation in pronunciation and increase their communicative com cpetence.

This study focuses on the students' development in understanding word stress placement and it was the primary focus which was investigated and analyzed through evaluation phase of the teaching learning process. This study focused on the three criteria of success in which he needed to analyze at the end of cycle. To get a bigger picture and understanding toward the findings, the result of this study will be displayed as follows: 


\section{Meetings $1,2,3$, and 4 in cycle I}

To analyze the three criteria of success, this study utilized recorder, observation check-list, and field notes. The result of analysis was that from the first test of the cycle 1 it was found there were eight of sixteen students who performed "good" score and one student who achieved "very good" score. It showed that the students' successful percentage that got success level from the first test of cycle I had not yet meet the criteria of success. Since the percentage approach employed formula $9 \times 100 \%: 16=56.25 \%$. 9 was the number of students who got success qualification; 16 was the number of all students, and 100 is the deviation scale. On the other hand, the percentage of classroom success should be $65 \%$ of the number of students.

Meanwhile the score of nine students falling into ranges from 65-87.5. It was not representative enough for this study to determine that the criteria of success have been achieved since the criteria of success for individual students should be 65; although there were nine students who got more than 65 but the number did not represent yet all class participants. Thus, in other words, the researcher argued the criteria of success will be achieved if more than half of students achieve score 65 or over it and there are at least $65 \%$ from total students got success level. Furthermore, individual score however was to judge the students' achievement individually.

The learners' participation in learning process was observed through classroom activities. Participation as a form of learning process was scrutinized quantitatively. The result of observation shows that the students were actively taking a part in classroom activities.

2. Meetings 1, 2, 3, and 4 in cycle 2

The result of evaluation on cycle II meeting 4 showed the significant development on students' understanding in English words stress. It was confirmed by the second test in cycle II; it was found that there were thirteen students who performed "success" qualification. It means that the number of students who achieved "success" from the second evaluation of cycle II has met the criteria of success; because the percentage approach employs formula $13 \times 100 \%: 16=$ $81.25 \% .13$ is the number of students who get "success" qualification; 16 is the number of all students, and 100 is the deviation scale. Since the number of students who got "success" qualification more than a half of the total number of students $(81.25 \%)$, so it is concluded that the criteria of classroom achievement has been achieved. This result was supported by previous findings (Buller, Buller, \& Everett, 1993; Field, 2005; Hahn, 2004) that recorded English dialogues were effetive to improve students' understanding in English words stress placement.

Meanwhile the higher score of thirteen students ranges from 65-100. It can be understood that it is absolutely reasonable for the the study to determine that the criteria of success have been achieved since the criteria of success for individual students should be 65 ; moreover, there were thirteen students who got at least 65 so the number has represented all class participants.

\section{CONCLUSION}

The objective of this study is to know the effectiveness of recorded English dialogues in developing the students understanding of English word stress for Islamic Education students. Taking into account of this objective, recorded English dialogues can be used to develop students understanding of English word stress at Islamic Education students effectively. The students are able to predict the words stress placement based on the scope of this research (stress placement in verbs and unsuffixed adjectives, stress placement in nouns and suffixed adjectives, stress placement in tonic and posttonic suffixes, neutral suffixes, and stress placement in Bahasa Indonesia) correctly.

Teaching English word stress through recorded English dialogue performed by the researcher is effective to develop students understanding of English word stress. The primary criteria to judge that the students have development are that from the score they gained from 
two phases of test. In the first test, the students' development reached $56.25 \%$ of nine students. Meanwhile, in the second test, students' development attained $81.25 \%$ of thirteen students. Since learning achievement is calculated based on the number of students who get the target score, so it can be stated that the learning achievement has been attained.

Comparing the result of student's achievement on first cycle, the students' achievement on second cycle has significant development due to the lower score that most students achieved more than 65 and the higher score is 95 . Compared to the criteria of success, the lower score in which most of students achieved is 65 ; it means that 65 have met criteria of success for individual students. The teaching-learning activities that employed this technique in which the researcher performed is able to develop students' enthusiasm, motivation, interest, response, and progress in joining the class with "high" category.

\section{BIBLIOGRAPHY}

Akbari, Z. (2015). Current Challenges in Teaching/Learning English for EFL learners: The case of Junior High School and High School. 199, 394-401. Procedia - Social and Behavioral Sciences. 199, 3. https://doi.org/10.1016/ j.sbspro.2015.07.524

Bin Tahir, S. Z. (2017). Multilingual teaching and learning at Pesantren Schools in Indonesia. Asian EFL Journal, 89, 74-94.

Buck, G. (2001). Assessing Listening. Cambridge: Cambridge University Press.

Buller, B., Buller, E., \& Everett, D. L. (1993). Stress placement, syllable structure, and minimality in Banawá. International Journal of American Linguistics, 59(3), 280-293.

Burden, P. R., \& Byrd, D. M. (1999). Methods for effective teaching, Second Edition. New York: Allyin and Bacon.

Depdiknas. (2004). Kurikulum GBPP untuk Bahasa Inggris. Jakarta: Depdiknas.

Field, J. (2005). Intelligibility and the listener: The role of lexical stress. TESOL quarterly, 39(3), 399-423.

Fraenkel, J. R., Wallen, N. E., \& Hyun, H. (2011). How to design and evaluate research in education. New York: McGraw-Hill Humanities/Social Sciences/Languages.

Fudge, E. (2015). English word-stress. Routledge.

Gilakjani, A. P. (2012). A study of factors affecting EFL learners' English pronunciation learning and the strategies for instruction. International Journal of Humanities and Social Science, 2(3), 119-128.

Hahn, L. D. (2004). Primary stress and intelligibility: Research to motivate the teaching of suprasegmentals. TESOL quarterly, 38(2), 201-223.

Kemmis, S., McTaggart, R., \& Nixon, R. (2013). The action research planner: Doing critical participatory action research. Springer Science \& Business Media.

Marzuki, A. G. (2016). Utilizing cooperative learning in islamic college students' classroom. IJEE (Indonesian Journal of English Education), 3(2), 123-139.

Marzuki, A. G. (2017). Developing speaking skill through oral report in an efl class in indonesia. Al-Ta'lim Journal, 24(3), 243-254.

Marzuki, A. G., Alim, N., \& Wekke, I. S. (2018). Improving the reading comprehension through cognitive reading strategies in language class of coastal area in indonesia. 156. IOP Publishing.

McKernan, J. (2013). Curriculum action research: A handbook of methods and resources for the reflective practitioner. Routledge.

McNiff, J. (2013). Action research: Principles and Practice. Chapman and Hall, Inc., London.: Routledge.

Perin, D. (2011). Facilitating student learning through contextualization: A review of evidence. Community College Review, 39(3), 268-295. 
Pitt, M. (2009). How are pronunciation variants of spoken words recognized? A test of generalization to newly learned words. Journal of Memory and Language, 61(1), 19-36.

Richard, C. J., \& Renandya, A. W. (2002). Methodology in language teaching-an anthology of current practice. Cambridge: Cambridge University Press.

Rofiqoh. (2000). Developing more effective pronunciation practice materials for the English major students at Tadulako university, Palu. University of South Australia., Adelaide.

Stringer, E. T. (2008). Action Research in Education. NJ: Pearson Prentice Hall.: Upper Saddle River. 